\title{
A Systematic Review of the Methods of Assessment of Gastro-Oesophageal Reflux in Anaesthetized Dogs
}

\author{
Anna Carolina Fernandez Alasia ${ }^{1}$, Olivier Levionnois ${ }^{2}\left(\mathbb{D}\right.$ and Mathieu Raillard ${ }^{1, *,+}+(\mathbb{D}$ \\ 1 School of Veterinary Science, Faculty of Science, Evelyn Williams Building No B10, The University of Sydney, \\ Sydney, NSW 2006, Australia; afer9691@uni.sydney.edu.au \\ 2 Anaesthesiology Section, Department of Clinical Veterinary Sciences, Vetsuisse Faculty, University of Berne, \\ 3012 Berne, Switzerland; olivier.levionnois@vetsuisse.unibe.ch \\ * Correspondence: mathieu_raillard@yahoo.it \\ † Current address: AniCura Regiondjursjukhuset Bagarmossen, Ljusnevägen 17, 12848 Bagarmossen, Sweden.
}

check for updates

Citation: Fernandez Alasia, A.C.; Levionnois, O.; Raillard, M. A Systematic Review of the Methods of Assessment of Gastro-Oesophageal Reflux in Anaesthetized Dogs. Animals 2021, 11, 852. https:// doi.org/10.3390/ani11030852

Academic Editor: Robert E. Meyer

Received: 23 February 2021

Accepted: 16 March 2021

Published: 18 March 2021

Publisher's Note: MDPI stays neutral with regard to jurisdictional claims in published maps and institutional affiliations.

Copyright: (c) 2021 by the authors. Licensee MDPI, Basel, Switzerland. This article is an open access article distributed under the terms and conditions of the Creative Commons Attribution (CC BY) license (https:/ / creativecommons.org/licenses/by/ $4.0 /)$.
Simple Summary: Regurgitation and gastro-oesophageal reflux (GOR) are common complications in dogs under anaesthesia. We reviewed the definitions and methods of GOR assessment in anaesthetized dogs published in 22 scientific papers to assess if studies were comparable (i.e., looking at the same thing). The definition of GOR implied the presence of fluids not reaching the mouth or nose in the oesophagus in all studies. Most studies measured the acidity in the oesophagus to state if fluids were present or not. The probes were not always placed in the same location and definitions varied. This means that it is complicated to compare findings of the different studies.

Abstract: We reviewed the definitions and methods of assessment of gastro-oesophageal reflux (GOR) in anaesthetized dogs. Three databases were used. Titles and abstracts were screened by two of the authors independently. A total of 22 studies was included in the analysis. The definition of GOR implied the presence of fluids not reaching the mouth or nose in the oesophagus in all studies. Most studies considered a change in $\mathrm{pH}$ using oesophageal $\mathrm{pH}$ meters as the sole method of assessment. Calibration of the $\mathrm{pH}$ probe was inconsistently reported. The position of the tip of the oesophageal probe was inconsistent and not always precisely described. The correct positioning in the intended location was verified in a limited number of studies. Some studies considered that GOR had happened for changes in $\mathrm{pH}$ below 4.0 or above 7.5 while others considered that GOR had happened when the $\mathrm{pH}$ dropped below 4.0 only. Some studies stated that the $\mathrm{pH}$ change had to be sustained for a minimum period of time (20 or $30 \mathrm{~s}$ ) whereas others did not mention any duration. The variability of definitions and methods of assessment of GOR in anaesthetized dogs precludes meaningful comparison of the findings. Re-evaluation and uniformization of the methods appear necessary.

Keywords: anaesthesia; complications; dogs; gastro-oesophageal reflux; regurgitation; risk

\section{Introduction}

Regurgitation and gastro-oesophageal reflux (GOR) are common complications in dogs undergoing general anaesthesia and can lead to significant morbidity and mortality. The literature highlights several risk factors (i.e., age, body weight, and type of surgery) and reports that the incidence of regurgitation and GOR may be influenced by a number of interventions (i.e., pre-operative fasting, positioning, and drugs). Reported incidences seem to vary reasonably for regurgitation [from $0.96 \%$ [1] to 5.5\% [2],] but enormously for GOR [from 5\% [3] to $87.5 \%$ [4]]. Such a huge variability is rather surprising. Before contrasting published findings and interventions aimed to reduce the development of regurgitation and GOR, it seems legitimate to question the methods used in the scientific literature.

The aim of this study was to review the definitions and methods of assessment of GOR in anaesthetized dogs in clinical veterinary practice. 


\section{Materials and Methods}

The PRISMA (Preferred Reporting Items for Systematic Reviews and Meta-Analyses) checklist was used.

The review protocol was not registered. The search was electronic. The search strategy was as follows: ((dogs OR canines OR dog OR canine) AND (anaesthetized OR anesthetized OR anaesthetize OR anesthetize OR anaesthetise OR anaesthesia OR anesthesia) AND (gastro-oesophageal reflux OR GER OR GOR OR gastroesophageal reflux or gastro-oesophageal reflux)). Three databases were used: Pubmed, Embase, and Scopus. The search was last performed on the 6 December 2020. References of relevant publications were also consulted. Titles and abstracts were screened by two of the authors independently. There was no a priori year restriction. Case reports, case series, conference papers. and non-English publications were excluded. The focus of this review being anaesthesia in clinical veterinary practice, studies including dogs as an experimental model and studies not focusing on GOR during the intra-anaesthetic period were excluded.

Information extracted included: (1) definitions and endpoints used in the article for regurgitation; (2) definitions and endpoints used in the article for GOR; (3) methods of assessment of regurgitation and GOR; (4) $\mathrm{pH}$ probe calibration if appropriate (method and timing); (5) equipment positioning, time of insertion, and removal; (6) verification of the appropriate location of the probe and timing of the check; (7) frequency of measurements; and (8) particular precautions (to limit probe dislodgement or effort to limit the iatrogenic GOR and regurgitation).

Descriptive statistics were performed where appropriate.

\section{Results}

The consort diagram for the search strategy is presented in Figure 1. A total of 164 studies were assessed for eligibility: 76 in Pubmed (56 were excluded: 54 not related to the question, one non-primary research, one abstract), 69 in Embase (48 were excluded: 43 not related to the question, two non-primary research, three abstracts); 19 in SCOPUS (9 were excluded as not related to question). Duplicates were removed. A total of 22 submissions was reviewed.

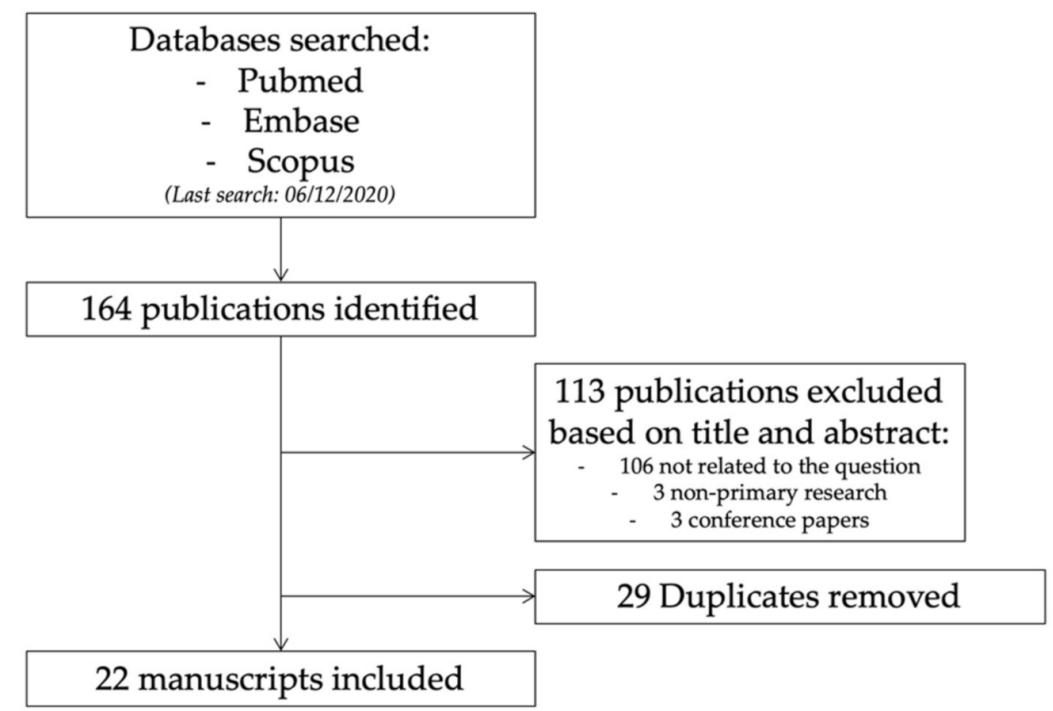

Figure 1. Consort diagram for search strategy.

The 22 manuscripts assessed in this review are reported in Table 1 . A total of 10/22 studies did not talk about regurgitation. The definition of regurgitation generally implied the passive and visible discharge of fluid from the mouth or nose. However, one study considered a change in $\mathrm{pH}$ in the pharynx as an episode of regurgitation. In that study, 
pharyngeal $\mathrm{pH}$ was measured when GOR episodes were identified, to evaluate the spread of the reflux.

Table 1. Reference number, authors, year of publication, and journal of the 22 manuscripts included in the review of the methods of assessment of gastro-oesophageal reflux (GOR) in anaesthetized dogs.

\begin{tabular}{|c|c|c|c|}
\hline Ref. & Authors & Year & Journal \\
\hline [5] & Roush JK, Keene BW, Eicker SW et al. & 1990 & Vet. Surg. \\
\hline [6] & Galatos AD, Raptopoulos D & 1995 & Vet. Rec. \\
\hline [7] & Galatos AD, Raptopoulos D & 1995 & Vet. Rec. \\
\hline [2] & Wilson DV, Evans AT, Miller R & 2005 & Am. J. Vet. Res. \\
\hline [8] & Wilson DV, Boruta DT, Evans AT & 2006 & Am. J. Vet. Res. \\
\hline [9] & Wilson DV, Evans AT, Mauer WA & 2006 & Am. J. Vet. Res. \\
\hline [10] & Wilson DV, Tom Evans A, Mauer WA & 2007 & Vet. Anaesth. Analg. \\
\hline [11] & Wilson DV, Evans AT & 2007 & Vet. Anaesth. Analg. \\
\hline [12] & Anagnostou TL, Savvas I, Kazakos GM et al. & 2009 & Vet. Anaesth. Analg. \\
\hline [13] & Panti A, Bennett RC, Corletto F et al. & 2009 & J. Small Anim. Pract. \\
\hline [14] & Favarato ES, de Souza MV, dos Santos Costa PR et al. & 2011 & Vet. Res. Commun. \\
\hline [15] & Favarato ES, Souza MV, Costa PR et al. & 2012 & Res. Vet. Sci. \\
\hline [16] & Zacuto AC, Marks SL, Osborn J et al. & 2012 & J. Vet. Intern. Med. \\
\hline [17] & Johnson RA & 2014 & Vet. Anaesth. Analg. \\
\hline [18] & Anagnostou TL, Savvas I, Kazakos GM et al. & 2015 & Vet. Anaesth. Analg. \\
\hline [3] & Savvas I, Raptopoulos D, Rallis T & 2016 & J. Am. Anim. Hosp. Assoc. \\
\hline [19] & Anagnostou TL, Kazakos GM, Savvas I et al. & 2017 & Vet. Anaesth. Analg. \\
\hline [20] & Shaver SL, Barbur LA, Jimenez DA et al. & 2017 & J. Am. Anim. Hosp. Assoc. \\
\hline [21] & Torrente C, Vigueras I, Manzanilla EG et al. & 2017 & J. Vet. Emerg. Crit. Care \\
\hline [22] & Viskjer S, Sjostrom L & 2017 & Am. J. Vet. Res. \\
\hline [4] & Lambertini C, Pietra M, Galiazzo G et al. & 2020 & Vet. Sci. \\
\hline [23] & Benzimra C, Cerasoli I, Rault D et al. & 2020 & J. Vet. Sci. \\
\hline
\end{tabular}

The definition of GOR implied the presence of fluids not reaching the mouth or nose in the oesophagus in all studies. The portion of the oesophagus considered was infrequently reported in the definition: "distal" or "caudal" or "lower" oesophagus in 8/22 papers. Most studies (20/22) identified the development of GOR through a change in oesophageal $\mathrm{pH}$. This was the sole method of assessment in 18/22 studies, while two studies used oesophagoscopy on top of the $\mathrm{pH}$ meter to visualise if reflux was present (i.e., non-acid reflux not causing $\mathrm{pH}$ changes). One study used a combined $\mathrm{pH} /$ impedance probe and considered a 50\% decrement in Ohms seen in two consecutive impedance channels in the distal oesophagus for $>2 \mathrm{~s}$ compared with the pre-episodic oesophageal baseline recording. One study retrospectively assessed the presence of gas, fluid, or alimentary content on CT (computed tomography) images.

In the 20 studies considering $\mathrm{pH}$ changes, 14 considered that GOR had happened for changes in $\mathrm{pH}$ "below 4.0 or above 7.5" while six considered that GOR had happened when the $\mathrm{pH}$ dropped below 4.0 only. The study using impedance changes categorized the $\mathrm{pH}$ of the reflux but this was not the criteria used to state if GOR had happened. In addition, for GOR to be confirmed, six studies stated that the $\mathrm{pH}$ change had to be sustained for a minimum period of time (20 or $30 \mathrm{~s}$ ) whereas the others did not mention any duration in $\mathrm{pH}$ change. 
Irrespective of definitions and main outcome measures, $21 / 22$ of the studies used $\mathrm{pH}$ meters. Calibration was reported in only 14 studies. Two-point calibration (generally with buffers of $\mathrm{pH} 1$ or 4 and $\mathrm{pH} 7$ ) was used.

The position of the tip of the oesophageal probe was inconsistent and not always described with precision. The distance between the lower incisors and the cranial margin of the 10th rib was externally measured with the dogs in lateral recumbency in 14 studies. However, the probe was advanced that distance in only 10/14 studies, whereas it was advanced that distance minus $5 \mathrm{~cm}$ in $4 / 14$. The distance between the upper canine and the distal border of the ninth rib (in a straight line with the dogs' head and neck in a "normal position") was measured in two studies where the probe was advanced that distance. It was estimated to position the tip of the probe about $7 \mathrm{~cm}$ cranially to the lower oesophageal sphincter in a "preliminary trial" where radiography was used. The probe was advanced until the ninth rib in one study. It was retrieved from the stomach, $6 \mathrm{~cm}$ cranially to the lower oesophageal sphincter (visualised through video-oesophagoscopy) in one study. The $\mathrm{pH}$ was measured at three different levels in the oesophagus (thoracic inlet, fifth and ninth rib) in one study. The location of the probe placement was not reported in $2 / 21$ studies. The correct positioning of the probe in the intended location was verified through endoscopy, chest radiographs, or fluoroscopy in only $5 / 21$ studies. The permanence of the probe in the appropriate location at the beginning and at the end or throughout the study was never checked.

The full results are presented in Appendix A.

\section{Discussion}

A variety of definitions and methods of assessment of GOR in anaesthetized dogs is present in the literature. Although oesophageal $\mathrm{pH}$ measurement is the method most commonly used, calibration, position of the probe, and cut-off values of $\mathrm{pH}$ to differentiate between GOR or not are inconsistent.

The method of analysis of $\mathrm{pH}$ is relative. This means that $\mathrm{pH}$ meters need to be appropriately calibrated [24]. The $\mathrm{pH}$ calibration curve is a combination of two curves, the $\mathrm{pH}$ and the $\mathrm{pOH}$ curves and is not linear. A slight deviation in the range of $\mathrm{pH}$ 6-8 is expected [24]. Generally, a pH meter should be calibrated every 2 to $3 \mathrm{~h}$ using at least two buffer solutions with known $\mathrm{pH}$ values close to the expected $\mathrm{pH}$ to be measured [24]. When considering a wide range of $\mathrm{pH}$, two-point calibration is not sufficient [24]. Also, given the effects of temperature on $\mathrm{pH}$ measurements [24], the question of calibrating the instruments at body temperature exists. In the present review, several studies used oesophageal $\mathrm{pH}$ meters without reporting any calibration. Studies reporting calibration used a two-point calibration, mostly using buffers of 1 or 4 and 7 while eight studies were defining GOR as a $\mathrm{pH}$ change below 4 or above 7.5. The accuracy of relevant $\mathrm{pH}$ values presented is questionable. Each $\mathrm{pH}$ unit change represents a 10-fold change in the hydrogen or hydroxyl ions concentration. The calibration might be less important if definitions considered sudden changes in $\mathrm{pH}$ as a proxy biomarker of GOR instead of numerical cut-off values.

Anatomic landmarks were commonly used to estimate the position of the lower oesophageal sphincter and the length of the probe to advance in the oesophagus. Most studies used the description proposed by Waterman and Hashim [25]. However, the length of the oesophageal probes advanced was variable. Also, the position of the tip of the probe was rarely checked. Depending on the volume of the refluxate, actual GOR could be missed, for example, in the case of $\mathrm{pH}$ measurements in the proximal oesophagus if material is present only caudally or if the tip of the probe is not in the liquid phase in the dependent oesophagus. Furthermore, there was no consensus on the definition of GOR and pH cut-off values of the refluxate. Although acid reflux seems to be observed more frequently than alkaline reflux in the articles examined, actual incidence of GOR might be underestimated in some studies. These points make comparisons between studies challenging from the perspective of actual incidence or efficacy of measures taken. 
Consequences of GOR can include oesophagitis, oesophageal stricture, and aspiration pneumonia [26,27]. Evidence in humans suggests that mixed reflux (acid mixed with bile acids) is more harmful to the oesophageal mucosa than acid reflux alone [28] and that bile reflux in the oesophagus can occur over a wide range of $\mathrm{pH}(2-8)$ [29]. Although the actual importance of this information in dogs undergoing a single anaesthesia and GOR episode is not known, the clinical relevance of changes in oesophageal $\mathrm{pH}$ as a sole marker of GOR is questionable. The position of the tip of the probe as well as the cut-off values of $\mathrm{pH}$ used to assess the presence vs absence of GOR might require re-evaluation. Although pH-metry seems commonly used, likely because of its wide availability and low cost, this technique alone might be insufficient. Combined $\mathrm{pH} /$ impedance probes with multiple impedance channels to evaluate the spread of the refluxate in the oesophagus, similar to the product used by Zacuto et al. (2012) [16] or Tarvin et al. (2016) [30], calibrated and in a well identified (checked) location, associated with biological analysis of the refluxate might offer a more relevant picture of GOR in anaesthetized dogs.

\section{Conclusions}

The variability of the GOR incidence found in the literature is likely due to a variety of factors (i.e., anaesthetic depth, transport, and position). However, the multiple definitions and methods of assessment of GOR in anaesthetized dogs present in the literature preclude meaningful comparison of the findings. Re-evaluation and uniformization of the methods seem necessary. Some aspects might warrant further investigation: (1) the relevance of the volume of the material regurgitated and how long the reflux remains in the oesophagus for; (2) the impact of anaesthesia on oesophageal motility; and (3) the importance of anaesthetic depth and the presence of monitoring equipment in the oesophageal lumen on the incidence of GOR.

Author Contributions: Conceptualization, M.R.; methodology, A.C.F.A., O.L., and M.R.; formal analysis, A.C.F.A., O.L., and M.R.; writing—original draft preparation, A.C.F.A.; writing-review and editing, M.R. and O.L.; supervision, M.R. All authors have read and agreed to the published version of the manuscript.

Funding: This research received no external funding.

Institutional Review Board Statement: Not applicable.

Informed Consent Statement: Not applicable.

Data Availability Statement: Data is contained within the article.

Conflicts of Interest: The authors declare no conflict of interest. 


\section{Appendix A}

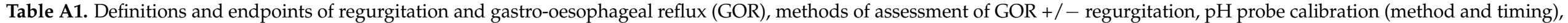

equipment positioning and placement check, frequency of measurements, and particular precautions in 22 scientific publications evaluating aspects of GOR in anaesthetized dogs.

\begin{tabular}{|c|c|c|c|c|c|c|c|c|}
\hline Article & $\begin{array}{l}\text { Gastro-Oesophageal } \\
\text { Regurgitation } \\
\text { Definition and } \\
\text { Endpoint(s) }\end{array}$ & $\begin{array}{l}\text { Gastro-Oesophageal } \\
\text { Reflux Definition and } \\
\text { Endpoint(s) }\end{array}$ & $\begin{array}{l}\text { Methods of } \\
\text { Assessment of GOR } \\
+/- \text { Regurgitation }\end{array}$ & $\begin{array}{l}\text { pH Probe Calibration } \\
\text { 1. Method } \\
\text { 2. Timing }\end{array}$ & $\begin{array}{l}\text { 1. Equipment Positioning } \\
\text { 2. Time Insertion } \\
\text { 3. Time Removal }\end{array}$ & $\begin{array}{l}\text { 1. Placement Check } \\
\text { 2. Timing }\end{array}$ & $\begin{array}{l}\text { Frequency of } \\
\text { Measurement }\end{array}$ & Particular Precautions \\
\hline $\begin{array}{c}\text { [5] } \\
\text { Roush et al., } 1990\end{array}$ & $\mathrm{~N} / \mathrm{A}$ & $\begin{array}{c}\text { "Reflux of gastric } \\
\text { contents and bile salts } \\
\text { into the oesophageal } \\
\text { lumen" } \\
\text { Oesophageal pH } 1 \text { H }<4.0 \\
\text { or }>7.5\end{array}$ & Oesophageal $\mathrm{pH}$ meter & $\begin{array}{l}\text { 1. Not reported } \\
\text { 2. N/A }\end{array}$ & $\begin{array}{l}\text { 1. Oesophageal pH } \\
\text { measurements made at the } \\
\text { thoracic inlet, heart base (level } \\
\text { of the fifth rib), and } \\
\text { gastroesophageal sphincter } \\
\text { (level of the tenth rib) } \\
\text { 2. N/A } \\
\text { 3. N/A }\end{array}$ & $\begin{array}{l}\text { 1. Not reported } \\
\text { 2. N/A }\end{array}$ & $\begin{array}{l}\text { Measurements } \\
\text { at minutes } 10 \\
\text { and } 30 \text {, and } \\
\text { every } 30 \mathrm{~min} \\
\text { thereafter until } \\
\text { recovery from } \\
\text { anaesthesia }\end{array}$ & Not reported \\
\hline
\end{tabular}


Table A1. Cont.

\begin{tabular}{|c|c|c|c|c|c|c|c|c|}
\hline Article & $\begin{array}{c}\text { Gastro-Oesophageal } \\
\text { Regurgitation } \\
\text { Definition and } \\
\text { Endpoint(s) }\end{array}$ & $\begin{array}{l}\text { Gastro-Oesophageal } \\
\text { Reflux Definition and } \\
\text { Endpoint(s) }\end{array}$ & $\begin{array}{c}\text { Methods of } \\
\text { Assessment of GOR } \\
+ \text { +- Regurgitation }\end{array}$ & $\begin{array}{l}\text { pH Probe Calibration } \\
\text { 1. Method } \\
\text { 2. Timing }\end{array}$ & $\begin{array}{l}\text { 1. Equipment Positioning } \\
\text { 2. Time Insertion } \\
\text { 3. Time Removal }\end{array}$ & $\begin{array}{l}\text { 1. Placement Check } \\
\text { 2. Timing }\end{array}$ & $\begin{array}{l}\text { Frequency of } \\
\text { Measurement }\end{array}$ & Particular Precautions \\
\hline $\begin{array}{c}{[7]} \\
\text { Galatos and } \\
\text { Raptopoulos } 1995\end{array}$ & $\begin{array}{l}\text { Not defined but } \\
\text { reported in one dog }\end{array}$ & $\begin{array}{l}\text { Lower oesophageal } \mathrm{pH} \\
\quad<4.0 \text { or }>7.5\end{array}$ & Oesophageal pH meter & $\begin{array}{l}\text { 1. Not reported } \\
\text { 2. N/A }\end{array}$ & $\begin{array}{l}\text { 1. Probe introduced in the } \\
\text { oesophagus via the } \\
\text { oropharynx the distance } \\
\text { measured from upper canine } \\
\text { and distal border of ninth rib } \\
\text { in a straight line with head } \\
\text { and neck in a "normal } \\
\text { position" (estimated about } \\
7 \mathrm{~cm} \text { cranial to lower } \\
\text { oesophageal sphincter in a } \\
\text { "prelimininary trial" where } \\
\text { radiography was used) } \\
\text { 2. Within } 5 \text { min from } \\
\text { anaesthesia induction } \\
\text { 3. After the end of } \\
\text { oesophageal pH monitoring, } \\
\text { electrode advanced in the } \\
\text { stomach for gastric pH } \\
\text { measurement }\end{array}$ & $\begin{array}{l}\text { 1. Not reported } \\
\text { 2. N/A }\end{array}$ & $\begin{array}{l}\text { Monitored } \\
\text { continuously, } \\
\text { recorded every } \\
5 \text { min from at } \\
\text { least } 60 \text { to } \\
140 \text { min after } \\
\text { induction of } \\
\text { anaesthesia }\end{array}$ & Not reported \\
\hline $\begin{array}{c}\text { [2] } \\
\text { Wilson et al., } 2005\end{array}$ & $\begin{array}{l}\text { "When refluxed fluid is } \\
\text { of sufficient volume to } \\
\text { reach the pharynx and } \\
\text { even drain from the } \\
\text { mouth. (...) Passive } \\
\text { discharge of liquid } \\
\text { from the mouth or nose } \\
\text { of a dog during } \\
\text { anaesthesia" } \\
\text { Direct visualization } \\
\text { and pH measurement }\end{array}$ & $\begin{array}{l}\text { “Reflux of gastric } \\
\text { contents into the } \\
\text { oesophagus" } \\
\text { Oesophageal pH } \\
\text { decreases to }<4.0 \text { (acidic } \\
\text { reflux) or increases to } \\
>7.5 \text { (biliary reflux) }\end{array}$ & $\begin{array}{l}\text { Oesophageal } \mathrm{pH} \text { meter } \\
+/ \text { - measurement } \mathrm{pH} \\
\text { of fluids discharged }\end{array}$ & $\begin{array}{l}\text { 1. Not reported } \\
\text { 2. N/A }\end{array}$ & $\begin{array}{l}\text { 1. Oesophageal probe taped to } \\
\text { an oesophageal stethoscope } \\
\text { advanced through the } \\
\text { oropharynx and into the } \\
\text { oesophagus to the distance } \\
\text { between the incisor tooth (on } \\
\text { the lower hemimandible) and } \\
\text { cranial margin of the head of } \\
\text { the 10th rib across the angle of } \\
\text { the mandible measured } \\
\text { externally } \\
\text { 2. After induction of } \\
\text { anaesthesia at a time when the } \\
\text { dog was judged to be at a } \\
\text { sufficiently deep plane of } \\
\text { anaesthesia to tolerate } \\
\text { insertion } \\
\text { 3. Removed prior to } \\
\text { extubation }\end{array}$ & $\begin{array}{l}\text { 1. Not reported } \\
\text { 2. N/A }\end{array}$ & $\begin{array}{l}\text { Continual } \\
\text { collection of } \\
\text { data for the } \\
\text { duration of } \\
\text { anaesthesia }\end{array}$ & Not reported \\
\hline
\end{tabular}


Table A1. Cont.

\begin{tabular}{|c|c|c|c|c|c|c|c|c|}
\hline Article & $\begin{array}{l}\text { Gastro-Oesophageal } \\
\text { Regurgitation } \\
\text { Definition and } \\
\text { Endpoint(s) }\end{array}$ & $\begin{array}{l}\text { Gastro-Oesophageal } \\
\text { Reflux Definition and } \\
\text { Endpoint(s) }\end{array}$ & $\begin{array}{c}\text { Methods of } \\
\text { Assessment of GOR } \\
\text { +/- Regurgitation }\end{array}$ & $\begin{array}{l}\mathrm{pH} \text { Probe Calibration } \\
\text { 1. Method } \\
\text { 2. Timing }\end{array}$ & $\begin{array}{l}\text { 1. Equipment Positioning } \\
\text { 2. Time Insertion } \\
\text { 3. Time Removal }\end{array}$ & $\begin{array}{l}\text { 1. Placement Check } \\
\text { 2. Timing }\end{array}$ & $\begin{array}{l}\text { Frequency of } \\
\text { Measurement }\end{array}$ & Particular Precautions \\
\hline $\begin{array}{c}{[8]} \\
\text { Wilson et al., } 2006\end{array}$ & $\begin{array}{l}\text { "Passive discharge of } \\
\text { liquid from the mouth } \\
\text { or nose" } \\
\text { Direct visualization } \\
\text { and pH of any fluid } \\
\text { that dripped from the } \\
\text { mouth or nose } \\
\text { measured }\end{array}$ & $\begin{array}{l}\text { Decrease in } \\
\text { oesophageal } \mathrm{pH} \text { to }<4 \\
\text { (reflux of gastric acid) } \\
\text { or an increase to }>7.5 \\
\text { (reflux of bile) for a } \\
\text { period of } \geq 30 \mathrm{~s}\end{array}$ & Oesophageal pH meter & $\begin{array}{c}\text { 1. Two-point } \\
\text { calibration (buffer } \\
\text { solutions pH } 1 \text { and } 7 \text { ) } \\
\text { 2. Within } 2 \text { h prior to } \\
\text { use }\end{array}$ & $\begin{array}{l}\text { 1. Tip of the probe taped to an } \\
\text { oesophageal stethoscope and } \\
\text { advanced through the } \\
\text { oropharynx into the } \\
\text { oesophagus the distance } \\
\text { between the incisor tooth on } \\
\text { the lower jaw and the cranial } \\
\text { margin of the 10th rib } \\
\text { (measured externally) } \\
\text { 2. After induction of } \\
\text { anaesthesia and endotracheal } \\
\text { intubation } \\
\text { 3. Prior to extubation }\end{array}$ & $\begin{array}{l}\text { 1. Not reported } \\
\text { 2. N/A }\end{array}$ & $\begin{array}{l}\text { Continuous } \\
\text { monitoring }\end{array}$ & $\begin{array}{l}\text { Probe placement was } \\
\text { performed by } 1 \text { of } 3 \\
\text { trained people } \\
\text { The probe was affixed } \\
\text { in place }\end{array}$ \\
\hline $\begin{array}{c}{[9]} \\
\text { Wilson et al., } 2006\end{array}$ & $\begin{array}{l}\text { "Passive discharge of } \\
\text { liquid from the mouth } \\
\text { or nose" } \\
\text { Direct visualization } \\
\text { and pH of any fluid } \\
\text { that dripped from the } \\
\text { mouth or nose } \\
\text { measured }\end{array}$ & $\begin{array}{c}\text { Decrease in } \\
\text { oesophageal } \mathrm{pH} \text { to }<4 \\
\text { (reflux of gastric acid) } \\
\text { or an increase to }>7.5 \\
\text { (reflux of bile) for a } \\
\text { period of } \geq 30 \mathrm{~s}\end{array}$ & Oesophageal pH meter & $\begin{array}{l}\text { 1. Two-point } \\
\text { calibration (buffer } \\
\text { solutions } \mathrm{pH} 1 \text { and } 7 \text { ) } \\
\text { 2. Within } 2 \mathrm{~h} \text { prior to } \\
\text { use }\end{array}$ & $\begin{array}{l}\text { 1. Tip of the probe taped to an } \\
\text { oesophageal stethoscope and } \\
\text { advanced through the } \\
\text { oropharynn into the } \\
\text { oesophagus the distance } \\
\text { between the incisor tooth on } \\
\text { the lower jaw and the cranial } \\
\text { margin of the 10th rib } \\
\text { (measured externally) } \\
\text { 2. After induction of } \\
\text { anaesthesia and endotracheal } \\
\text { intubation } \\
\text { 3. Prior to extubation }\end{array}$ & $\begin{array}{l}\text { 1. Not reported } \\
\text { 2. N/A }\end{array}$ & $\begin{array}{l}\text { Continuous } \\
\text { monitoring }\end{array}$ & $\begin{array}{l}\text { Probe placement was } \\
\text { performed by } 1 \text { of } 3 \\
\text { trained people } \\
\text { The probe was affixed } \\
\text { in place }\end{array}$ \\
\hline $\begin{array}{l}{[10]} \\
\text { Wilson et al., } 2007\end{array}$ & $\begin{array}{l}\text { "Passive discharge of } \\
\text { liquid from the mouth } \\
\text { or nose" } \\
\text { Direct visualization } \\
\text { and pH of any fluid } \\
\text { that dripped from the } \\
\text { mouth or nose } \\
\text { measured }\end{array}$ & $\begin{array}{c}\text { Decrease in } \\
\text { oesophageal } \mathrm{pH} \text { to }<4 \\
\text { (reflux of gastric acid) } \\
\text { or an increase to }>7.5 \\
\text { (reflux of bile) for a } \\
\text { period of } \geq 30 \mathrm{~s}\end{array}$ & Oesophageal $\mathrm{pH}$ meter & $\begin{array}{l}\text { 1. Two-point } \\
\text { calibration (buffer } \\
\text { solutions pH } 1 \text { and } 7 \text { ) } \\
\text { 2. Within } 2 \mathrm{~h} \text { prior to } \\
\text { use }\end{array}$ & $\begin{array}{l}\text { 1. Tip of the probe taped to an } \\
\text { oesophageal stethoscope and } \\
\text { advanced through the } \\
\text { oropharynx into the } \\
\text { oesophagus the distance } \\
\text { between the incisor tooth on } \\
\text { the lower jaw and the cranial } \\
\text { margin of the 10th rib } \\
\text { (measured externally) } \\
\text { 2. After induction of } \\
\text { anaesthesia and endotracheal } \\
\text { intubation } \\
\text { 3. Prior to extubation }\end{array}$ & $\begin{array}{l}\text { 1. Not reported } \\
\text { 2. N/A }\end{array}$ & $\begin{array}{l}\text { Continuous } \\
\text { monitoring }\end{array}$ & $\begin{array}{l}\text { Probe placement was } \\
\text { performed by } 1 \text { of } 3 \\
\text { trained people } \\
\text { The probe was affixed } \\
\text { in place }\end{array}$ \\
\hline
\end{tabular}


Table A1. Cont.

\begin{tabular}{|c|c|c|c|c|c|c|c|c|}
\hline Article & $\begin{array}{c}\text { Gastro-Oesophageal } \\
\text { Regurgitation } \\
\text { Definition and } \\
\text { Endpoint(s) }\end{array}$ & $\begin{array}{l}\text { Gastro-Oesophageal } \\
\text { Reflux Definition and } \\
\text { Endpoint(s) }\end{array}$ & $\begin{array}{c}\text { Methods of } \\
\text { Assessment of GOR } \\
+/- \text { Regurgitation }\end{array}$ & $\begin{array}{l}\mathrm{pH} \text { Probe Calibration } \\
\text { 1. Method } \\
\text { 2. Timing }\end{array}$ & $\begin{array}{l}\text { 1. Equipment Positioning } \\
\text { 2. Time Insertion } \\
\text { 3. Time Removal }\end{array}$ & $\begin{array}{l}\text { 1. Placement Check } \\
\text { 2. Timing }\end{array}$ & $\begin{array}{l}\text { Frequency of } \\
\text { Measurement }\end{array}$ & Particular Precautions \\
\hline $\begin{array}{c}\text { [11] } \\
\text { Wilson and Evans } 2007\end{array}$ & $\begin{array}{l}\text { "Passive discharge of } \\
\text { liquid from the mouth } \\
\text { or nose of a dog during } \\
\text { general anaesthesia" } \\
\text { Direct visualization }\end{array}$ & $\begin{array}{l}\text { Observation of } 30 \mathrm{~s} \text { or } \\
\text { longer of a decrease in } \\
\text { oesophageal } \mathrm{pH} \text { to }<4 \\
\text { (reflux of gastric acid) }\end{array}$ & Oesophageal pH meter & $\begin{array}{l}\text { 1. Two-point } \\
\text { calibration (buffer } \\
\text { solutions } \mathrm{pH} 1 \text { and } 7 \text { ) } \\
\text { 2. Within } 2 \mathrm{~h} \text { prior to } \\
\text { use }\end{array}$ & $\begin{array}{l}\text { 1. Tip of the probe advanced } \\
\text { through the oropharynx into } \\
\text { the oesophagus the } \\
\text { pre-measured distance } \\
\text { between the incisor tooth on } \\
\text { the lower jaw and the cranial } \\
\text { margin of the head of the 10th } \\
\text { rib measured externally } \\
\text { 2. Probe inserted after } \\
\text { induction of anesthesia and } \\
\text { endotracheal intubation } \\
\text { 3. Probe removed prior to } \\
\text { extubation }\end{array}$ & $\begin{array}{l}\text { 1. Not reported } \\
\text { 2. N/A }\end{array}$ & $\begin{array}{l}\text { Continual data } \\
\text { collection }\end{array}$ & $\begin{array}{l}\text { Probe placement } \\
\text { performed by one of } \\
\text { three trained people. } \\
\text { The probe was affixed } \\
\text { in place. }\end{array}$ \\
\hline $\begin{array}{c}{[12]} \\
\text { Anagnostou et al., } 2009\end{array}$ & $\mathrm{~N} / \mathrm{A}$ & $\begin{array}{l}\mathrm{pH} \text { values of }>7.5 \\
\text { (alkaline reflux) or }<4 \\
\text { (acid reflux) in the } \\
\text { lower oesophagus }\end{array}$ & Oesophageal pH meter & $\begin{array}{l}\text { 1. Two-point } \\
\text { calibration (buffer } \\
\text { solutions pH } 4 \text { and } 7 \text { ) } \\
\text { 2. "Previously" }\end{array}$ & $\begin{array}{l}\text { 1. pH-meter inserted into the } \\
\text { oesophagus through the oral } \\
\text { cavity. Length determined } \\
\text { subtracting } 5 \mathrm{~cm} \text { from } \\
\text { pre-measured distance } \\
\text { between lower incisor tooth } \\
\text { (animal in left lateral } \\
\text { recumbency) and anterior } \\
\text { border of the head of the 10th } \\
\text { rib through the angle of the } \\
\text { mandible } \\
\text { 2. Immediately after } \\
\text { intubation of the trachea and } \\
\text { connection of the endotracheal } \\
\text { tube to the anaesthetic } \\
\text { machine } \\
\text { 3. After completion of } 1 \mathrm{~h} \text { of } \\
\text { continuous oesophageal pH } \\
\text { monitoring }\end{array}$ & $\begin{array}{l}\text { 1. Not reported } \\
\text { 2. N/A }\end{array}$ & $\begin{array}{l}\text { Monitored } \\
\text { continuously for } \\
60 \text { min after } \\
\text { induction of } \\
\text { anaesthesia }\end{array}$ & $\begin{array}{l}\text { Dogs placed in dorsal } \\
\text { recumbency } \\
\text { immediately after } \\
\text { securing the probe. } \\
\text { During procedures and } \\
\text { position changes, } \\
\text { special attention was } \\
\text { paid to avoiding } \\
\text { application of pressure } \\
\text { to the abdominal wall }\end{array}$ \\
\hline
\end{tabular}


Table A1. Cont.

\begin{tabular}{|c|c|c|c|c|c|c|c|c|}
\hline Article & $\begin{array}{l}\text { Gastro-Oesophageal } \\
\text { Regurgitation } \\
\text { Definition and } \\
\text { Endpoint(s) }\end{array}$ & $\begin{array}{l}\text { Gastro-Oesophageal } \\
\text { Reflux Definition and } \\
\text { Endpoint(s) }\end{array}$ & $\begin{array}{c}\text { Methods of } \\
\text { Assessment of GOR } \\
+/- \text { Regurgitation }\end{array}$ & $\begin{array}{l}\text { pH Probe Calibration } \\
\text { 1. Method } \\
\text { 2. Timing }\end{array}$ & $\begin{array}{l}\text { 1. Equipment Positioning } \\
\text { 2. Time Insertion } \\
\text { 3. Time Removal }\end{array}$ & $\begin{array}{l}\text { 1. Placement Check } \\
\text { 2. Timing }\end{array}$ & $\begin{array}{l}\text { Frequency of } \\
\text { Measurement }\end{array}$ & Particular Precautions \\
\hline $\begin{array}{c}\text { [13] } \\
\text { Panti et al., } 2009\end{array}$ & $\begin{array}{l}\text { "Return of partially } \\
\text { digested food from the } \\
\text { stomach to the mouth" }\end{array}$ & $\begin{array}{l}\text { Abrupt decrease in } \\
\text { distal oesophageal pH } \\
\text { below } 4\end{array}$ & Oesophageal pH meter & $\begin{array}{l}\text { 1. Two-point } \\
\text { calibration (buffer } \\
\text { solutions pH } 4 \text { and } 7 \text { ) } \\
\text { 2. Approximately every } \\
\text { three cases and at least } \\
\text { once a week }\end{array}$ & $\begin{array}{l}\text { Probe placed inside a } \\
\text { protective polythene tube. and } \\
\text { inserted into the distal } \\
\text { oesophagus. The probe was } \\
\text { inserted into the oesophagus, } \\
\text { with the tip at the level of the } \\
\text { ninth rib, which is about } 7 \mathrm{~cm} \\
\text { rostral to the LOS (Position of } \\
\text { the lower oesophageal } \\
\text { sphincter estimated the length } \\
\text { between the incisor of the } \\
\text { lower jaw and the cranial } \\
\text { border of the head of the } 10 \text { th } \\
\text { rib, measured externally with } \\
\text { the animal in lateral } \\
\text { recumbency) } \\
\text { 2. Immediately after induction } \\
\text { of anaesthesia } \\
\text { 3. Not reported }\end{array}$ & $\begin{array}{l}\text { 1. Not reported } \\
\text { 2. N/A }\end{array}$ & $\begin{array}{l}\text { Recorded every } \\
\text { five minutes } \\
\text { during } \\
\text { anaesthesia }\end{array}$ & $\begin{array}{l}\text { The same operator } \\
\text { positioned the } \\
\text { oesophageal } \mathrm{pH} \text { probe } \\
\text { in each dog }\end{array}$ \\
\hline $\begin{array}{l}\text { [14] } \\
\text { Favarato et al., } 2011\end{array}$ & $\mathrm{~N} / \mathrm{A}$ & $\begin{array}{l}\text { "Presence of acid reflux } \\
\text { in the oesophagus" } \\
\text { Oesophageal } \mathrm{pH}<4 \\
\text { and visualisation of } \\
\text { content through } \\
\text { video-oesophagoscopy }\end{array}$ & $\begin{array}{l}\text { Oesophageal pH meter } \\
\text { and } \\
\text { video-oesophago-scopy }\end{array}$ & $\begin{array}{c}\text { 1. Two-point } \\
\text { calibration (buffer } \\
\text { solutions pH } 1.0 \text { and } \\
7.0) \\
\text { 2. Maximum } 1 \mathrm{~h} \text { before } \\
\text { the procedure }\end{array}$ & $\begin{array}{l}\text { 1. Close and cranially to the } \\
\text { oesophago-gastric juntion } \\
\text { (measuring the distance } \\
\text { between the mandible incisor } \\
\text { teeth and the cranial border of } \\
\text { the tenth rib through the angle } \\
\text { of the mandible after the } \\
\text { pre-anaesthetic medication, } \\
\text { the animals positioned in left } \\
\text { lateral recumbency) } \\
\text { 2. "Intra-operatively" } \\
\text { 3. Catheter removed } \\
\text { immediately after } \\
\text { esophagoscopy }\end{array}$ & $\begin{array}{c}1 . \\
\text { Video-oesophago-scopy } \\
\text { 2. Immediately after } \\
\text { surgery }\end{array}$ & $\begin{array}{l}\text { Constantly } \\
\text { monitored, } \\
\text { variations } \\
\text { recorded }\end{array}$ & $\begin{array}{l}\text { Dogs maintained in a } \\
\text { dorsal horizontal } \\
\text { recumbency, on a } \\
\text { surgical table, during } \\
\text { the surgical procedure. } \\
\text { Lateral decubitus after } \\
\text { the end of surgery. No } \\
\text { position changes } \\
\text { allowed during the } \\
\text { evaluation period }\end{array}$ \\
\hline $\begin{array}{l}\text { [15] } \\
\text { Favarato et al., } 2012\end{array}$ & $\mathrm{~N} / \mathrm{A}$ & $\begin{array}{l}\text { pH lower than } 4 \\
\text { considered an acid } \\
\text { reflux episode; } \\
\text { confirmation of the } \\
\text { non-acid reflux } \\
\text { obtained by } \\
\text { esophagoscopy } \\
\text { conducted on all the } \\
\text { animals immediately } \\
\text { after surgery to } \\
\text { evaluate the presence } \\
\text { of visible reflux in the } \\
\text { oesophageal lumen }\end{array}$ & $\begin{array}{l}\text { Oesophageal pH meter } \\
\text { and } \\
\text { video-oesophago-scopy }\end{array}$ & $\begin{array}{l}\text { 1. Not reported } \\
\text { 2. N/A }\end{array}$ & $\begin{array}{l}\text { 1. "Close and cranially to the } \\
\text { oesophago-gastric junction" } \\
\text { 2. N/A } \\
\text { 3. N/A }\end{array}$ & $\begin{array}{l}\text { 1. Not reported } \\
\text { 2. N/A }\end{array}$ & $\begin{array}{l}\text { Monitoring } \\
\text { throughout the } \\
\text { anaesthetic } \\
\text { procedure, with } \\
\text { all the pH } \\
\text { variations } \\
\text { recorded }\end{array}$ & N/A \\
\hline
\end{tabular}


Table A1. Cont.

\begin{tabular}{|c|c|c|c|c|c|c|c|c|}
\hline Article & $\begin{array}{l}\text { Gastro-Oesophageal } \\
\text { Regurgitation } \\
\text { Definition and } \\
\text { Endpoint(s) } \\
\end{array}$ & $\begin{array}{l}\text { Gastro-Oesophageal } \\
\text { Reflux Definition and } \\
\text { Endpoint(s) }\end{array}$ & $\begin{array}{c}\text { Methods of } \\
\text { Assessment of GOR } \\
+/- \text { Regurgitation }\end{array}$ & $\begin{array}{l}\mathrm{pH} \text { Probe Calibration } \\
\text { 1. Method } \\
\text { 2. Timing }\end{array}$ & $\begin{array}{l}\text { 1. Equipment Positioning } \\
\text { 2. Time Insertion } \\
\text { 3. Time Removal }\end{array}$ & $\begin{array}{l}\text { 1. Placement Check } \\
\text { 2. Timing }\end{array}$ & $\begin{array}{l}\text { Frequency of } \\
\text { Measurement }\end{array}$ & Particular Precautions \\
\hline $\begin{array}{l}\text { [16] } \\
\text { Zacuto et al., } 2012\end{array}$ & $\mathrm{~N} / \mathrm{A}$ & $\begin{array}{l}50 \% \text { decrement in ohms } \\
\text { seen in } 2 \text { consecutive } \\
\text { impedance channels in } \\
\text { the distal oesophagus } \\
\text { for }>2 \mathrm{~s} \text { from the } \\
\text { pre-episodic } \\
\text { oesophageal baseline } \\
\text { recording. The } \mathrm{pH} \text { of } \\
\text { the refluxate was } \\
\text { classified as strongly } \\
\text { acidic }(\mathrm{pH}<4.0) \text {, } \\
\text { weakly acidic } \\
(4.0<\mathrm{pH}<7.0) \text {, or } \\
\text { nonacidic }(\mathrm{pH} \geq 7.0)\end{array}$ & $\begin{array}{l}\text { Oesophageal multi-use } \\
\mathrm{pH} / \text { impedance probe }\end{array}$ & $\begin{array}{c}\text { 1. Probe calibrated in } \\
\text { buffer solutions of } \mathrm{pH} \\
4.0 \text { and } 7.0 \\
\text { 2. Within } 10 \text { min of use }\end{array}$ & $\begin{array}{l}\text { 1. The esophageal probe was } \\
\text { introduced into the esophagus } \\
\text { via the oral cavity by use of a } \\
\text { loop snare passed through the } \\
\text { biopsy channel of a fibreoptic } \\
\text { endoscope The probe was } \\
\text { advanced into the greater } \\
\text { curvature region of the } \\
\text { stomach to record gastric } \mathrm{pH} \\
\text { for } 2 \text { min before probe } \\
\text { placement in the distal } \\
\text { esophagus. After recording of } \\
\text { gastric pH, the pH sensor on } \\
\text { the esophageal probe was } \\
\text { positioned } 6 \mathrm{~cm} \text { proximal to } \\
\text { the gastroesophageal junction } \\
\text { in all dogs, and no portion of } \\
\text { the probe traversed the LES } \\
\text { during the recording period } \\
\text { 2. Immediately after induction } \\
\text { 3. Immediately before } \\
\text { extubation }\end{array}$ & $\begin{array}{l}\text { 1. Oesophago-scopy } \\
\text { 2. During placement }\end{array}$ & $\begin{array}{l}\text { Esophageal pH } \\
\text { and impedance } \\
\text { were recorded } \\
\text { throughout the } \\
\text { surgical } \\
\text { procedure }\end{array}$ & $\begin{array}{l}\text { Probe placement was } \\
\text { performed in all dogs } \\
\text { by } 1 \text { of } 2 \text { investigators } \\
\text { skilled in endoscope } \\
\text { handling to ensure } \\
\text { consistency in the } \\
\text { positioning of the probe } \\
\text { The probe then was } \\
\text { secured in place using } \\
\text { tape wrapped around } \\
\text { the maxilla }\end{array}$ \\
\hline
\end{tabular}


Table A1. Cont.

\begin{tabular}{|c|c|c|c|c|c|c|c|c|}
\hline Article & $\begin{array}{c}\text { Gastro-Oesophageal } \\
\text { Regurgitation } \\
\text { Definition and } \\
\text { Endpoint(s) }\end{array}$ & $\begin{array}{l}\text { Gastro-Oesophageal } \\
\text { Reflux Definition and } \\
\text { Endpoint(s) }\end{array}$ & $\begin{array}{c}\text { Methods of } \\
\text { Assessment of GOR } \\
+/- \text { Regurgitation }\end{array}$ & $\begin{array}{l}\text { pH Probe Calibration } \\
\text { 1. Method } \\
\text { 2. Timing }\end{array}$ & $\begin{array}{l}\text { 1. Equipment Positioning } \\
\text { 2. Time Insertion } \\
\text { 3. Time Removal }\end{array}$ & $\begin{array}{l}\text { 1. Placement Check } \\
\text { 2. Timing }\end{array}$ & $\begin{array}{l}\text { Frequency of } \\
\text { Measurement }\end{array}$ & Particular Precautions \\
\hline $\begin{array}{c}{[18]} \\
\text { Anagnostou et al., } 2015\end{array}$ & N/A & $\begin{array}{l}\text { Lower oesophageal pH } \\
\text { values of }>7.5 \text { (alkaline } \\
\text { reflux) or }<4 \text { (acid } \\
\text { reflux) }\end{array}$ & Oesophageal $\mathrm{pH}$ meter & $\begin{array}{l}\text { 1. Two-point } \\
\text { calibration (buffer } \\
\text { solutions pH } 4 \text { and 7) } \\
\text { 2. "previously" }\end{array}$ & $\begin{array}{l}\text { 1. Probe inserted into the } \\
\text { oesophagus through the oral } \\
\text { cavity; length subtracting } 5 \mathrm{~cm} \\
\text { from the pre-measured } \\
\text { distance between the lower } \\
\text { incisor tooth and the anterior } \\
\text { border of the head of the 10th } \\
\text { rib through the angle of the } \\
\text { mandible (animal in left lateral } \\
\text { recumbency) } \\
\text { 2. Immediately after } \\
\text { intubation of the trachea and } \\
\text { connection of the endotracheal } \\
\text { tube to the anaesthetic } \\
\text { machine } \\
\text { 3. Oesophageal probe } \\
\text { removed on completion of } \\
\text { surgery before discontinuing } \\
\text { administration }\end{array}$ & $\begin{array}{l}\text { 1. Not reported } \\
\text { 2. N/A }\end{array}$ & $\begin{array}{c}\text { Monitored } \\
\text { continuously } \\
\text { after induction } \\
\text { of anaesthesia } \\
\text { and throughout } \\
\text { surgery }\end{array}$ & $\begin{array}{l}\text { Immediately after } \\
\text { securing the probe in } \\
\text { place, the animal was } \\
\text { placed in dorsal } \\
\text { recumbency. } \\
\text { During introduction of } \\
\text { the pH-measuring } \\
\text { probe, change of the } \\
\text { animals' position, and } \\
\text { aseptic preparation } \\
\text { (clipping, scrubbing), } \\
\text { special attention was } \\
\text { paid to avoiding } \\
\text { application of excessive } \\
\text { pressure to the } \\
\text { abdominal wall }\end{array}$ \\
\hline $\begin{array}{c}{[3]} \\
\text { Savvas et al., } 2016\end{array}$ & $\begin{array}{l}\text { pH-change at the } \\
\text { pharynx, measured } \\
\text { when GOR was } \\
\text { observed }\end{array}$ & $\underset{>7.5}{\text { Oesophageal } \mathrm{pH}}<4$ or & $\begin{array}{l}\text { Oesophageal }+/- \\
\text { upper oesophageal } \mathrm{pH} \\
\text { meter }\end{array}$ & $\begin{array}{l}\text { 1. Not reported } \\
\text { 2. Not reported }\end{array}$ & $\begin{array}{l}\text { 1. Oesophageal probe: } 5 \mathrm{~cm} \\
\text { above the lower oesophageal } \\
\text { sphincter, estimated by } \\
\text { measuring the length from } \\
\text { lower jaw incisor tooth to the } \\
\text { anterior border of the head of } \\
\text { the tenth rib } \\
\text { 2. Following intubation of the } \\
\text { trachea } \\
\text { 3. pH recording was } \\
\text { discontinued just prior to } \\
\text { extubation } \\
\text { NB: Second pH probe with its } \\
\text { tip at the upper oesophageal } \\
\text { sphincter (at the level of the } \\
\text { larynx) when GOR observed }\end{array}$ & $\begin{array}{l}\text { 1. Not reported } \\
\text { 2. N/A }\end{array}$ & $\begin{array}{l}\text { Constantly } \\
\text { monitored, } \\
\text { recorded every } \\
5 \text { min }\end{array}$ & $\begin{array}{l}\text { No transportation of } \\
\text { the animals to another } \\
\text { operation room. All } \\
\text { possible precautions } \\
\text { were taken to prevent } \\
\text { increases in } \\
\text { intra-abdominal } \\
\text { pressure (from } \\
\text { manipulations of the } \\
\text { animals during } \\
\text { handling and surgery) }\end{array}$ \\
\hline
\end{tabular}


Table A1. Cont.

\begin{tabular}{|c|c|c|c|c|c|c|c|c|}
\hline Article & $\begin{array}{l}\text { Gastro-Oesophageal } \\
\text { Regurgitation } \\
\text { Definition and } \\
\text { Endpoint(s) }\end{array}$ & $\begin{array}{l}\text { Gastro-Oesophageal } \\
\text { Reflux Definition and } \\
\text { Endpoint(s) }\end{array}$ & $\begin{array}{c}\text { Methods of } \\
\text { Assessment of GOR } \\
+/- \text { Regurgitation }\end{array}$ & $\begin{array}{l}\text { pH Probe Calibration } \\
\text { 1. Method } \\
\text { 2. Timing }\end{array}$ & $\begin{array}{l}\text { 1. Equipment Positioning } \\
\text { 2. Time Insertion } \\
\text { 3. Time Removal }\end{array}$ & $\begin{array}{l}\text { 1. Placement Check } \\
\text { 2. Timing }\end{array}$ & $\begin{array}{l}\text { Frequency of } \\
\text { Measurement }\end{array}$ & Particular Precautions \\
\hline $\begin{array}{c}{[19]} \\
\text { Anagnostou et al., } 2017\end{array}$ & $\begin{array}{l}\text { "Reflux material } \\
\text { observed at the external } \\
\text { nares or in the mouth" }\end{array}$ & $\begin{array}{l}\text { Whenever a } \mathrm{pH} \text { value }> \\
7.5 \text { (alkaline reflux) or } \\
<4.0 \text { (acid reflux) was } \\
\text { recorded }\end{array}$ & Oesophageal pH meter & $\begin{array}{l}\text { 1. Two-point } \\
\text { calibration (buffer } \\
\text { solutions pH } 4 \text { and 7) } \\
\text { 2. Before each use }\end{array}$ & $\begin{array}{l}\text { 1. Probe introduced into the } \\
\text { oesophageal lumen through } \\
\text { the oral cavity. The distance } \\
\text { between the lower incisor } \\
\text { teeth (animal in left lateral } \\
\text { recumbency) and the anterior } \\
\text { border of the head of the } 10 \text { th } \\
\text { rib through the angle of the } \\
\text { mandible was measured } \\
\text { considered to correspond to } \\
\text { the approximate location of } \\
\text { the posterior oesophageal } \\
\text { sphincter; the final length of } \\
\text { the pH measuring probe that } \\
\text { was inserted into the } \\
\text { oesophageal lumen was } \\
\text { calculated by subtracting } 5 \mathrm{~cm} \\
\text { from this measured distance } \\
\text { 2. Immediately after tracheal } \\
\text { intubation and connection of } \\
\text { the endotracheal tube to the } \\
\text { anaesthetic machine } \\
\text { 3. After completion of surgery, } \\
\text { administration of halothane } \\
\text { discontinued and pH probe } \\
\text { withdrawn }\end{array}$ & $\begin{array}{l}\text { 1. Not reported } \\
\text { 2. N/A }\end{array}$ & $\begin{array}{l}\text { Continuous } \\
\text { monitoring }\end{array}$ & $\begin{array}{l}\text { Immediately after } \\
\text { securing the probe in } \\
\text { place, the animal was } \\
\text { placed in sternal } \\
\text { recumbency on a } \\
\text { horizontal table. } \\
\text { Application of } \\
\text { excessive pressure to } \\
\text { the abdominal wall or } \\
\text { to the surgical area that } \\
\text { could potentially cause } \\
\text { GOR was avoided at all } \\
\text { times and especially } \\
\text { during introduction of } \\
\text { the pH measuring } \\
\text { probe, change of } \\
\text { recumbency, clipping } \\
\text { and scrubbing. }\end{array}$ \\
\hline $\begin{array}{c}{[20]} \\
\text { Shaver et al., } 2017\end{array}$ & $\begin{array}{l}\text { "Gastric contents } \\
\text { refluxing to the } \\
\text { oropharynx" }\end{array}$ & $\begin{array}{c}\text { Prolonged }(>20 \mathrm{~s}) \\
\text { decreases }(<4.0) \text { or } \\
\text { increases }(>7.5) \text { in } \\
\text { oesophageal } \mathrm{pH}\end{array}$ & Oesophageal pH meter & $\begin{array}{l}\text { 1. Two-point } \\
\text { calibration (buffer } \\
\text { solutions pH } 4 \text { and } 7 \text { ) } \\
\text { 2. Immediately before } \\
\text { use }\end{array}$ & $\begin{array}{l}\text { 1. Probe inserted orally and } \\
\text { advanced a distance measured } \\
\text { from the incisors to the cranial } \\
\text { margin of the tenth rib to } \\
\text { result in a predictable location } \\
\text { just proximal to the lower } \\
\text { oesophageal sphincter } \\
\text { 2. After induction of } \\
\text { anaesthesia } \\
\text { 3. Just prior to patient } \\
\text { endotracheal extubation }\end{array}$ & $\begin{array}{l}\text { 1. Thoracic radiograph } \\
\text { 2. Immediately after } \\
\text { placement }\end{array}$ & $\begin{array}{l}\text { Continuous } \\
\text { monitoring of } \\
\text { oesophageal pH, } \\
\text { recorded at } \\
5 \text { min intervals }\end{array}$ & $\begin{array}{l}\text { Probe placed by a } \\
\text { single surgeon } \\
\text { Medical tape was fixed } \\
\text { to the probe at the level } \\
\text { of the first premolar } \\
\text { and stapled to the } \\
\text { dog's upper lip using } \\
\text { surgical staples }\end{array}$ \\
\hline $\begin{array}{c}\text { [21] } \\
\text { Torrente et al., } 2017\end{array}$ & $\begin{array}{c}\text { "Passive ejection of } \\
\text { gastric or oesophageal } \\
\text { content from the mouth } \\
\text { or nose" } \\
\text { Direct visualisation }\end{array}$ & $\begin{array}{c}\text { Oesophageal } \mathrm{pH}<4 \\
\text { was considered an acid } \\
\text { reflux event }\end{array}$ & Oesophageal pH meter & $\begin{array}{l}\text { 1. Not reported } \\
\text { 2. N/A }\end{array}$ & $\begin{array}{l}\text { 1. Oesophageal probe during } \\
\text { anaesthesia and just before } \\
\text { return to full consciousness } \\
\text { (no more detail) } \\
\text { 2. N/A } \\
\text { 3. N/A }\end{array}$ & $\begin{array}{l}\text { 1. Not reported } \\
\text { 2. N/A }\end{array}$ & Not reported & Not reported \\
\hline
\end{tabular}


Table A1. Cont.

\begin{tabular}{|c|c|c|c|c|c|c|c|c|}
\hline Article & $\begin{array}{l}\text { Gastro-Oesophageal } \\
\text { Regurgitation } \\
\text { Definition and } \\
\text { Endpoint(s) }\end{array}$ & $\begin{array}{l}\text { Gastro-Oesophageal } \\
\text { Reflux Definition and } \\
\text { Endpoint(s) }\end{array}$ & $\begin{array}{c}\text { Methods of } \\
\text { Assessment of GOR } \\
+/- \text { Regurgitation }\end{array}$ & $\begin{array}{l}\text { pH Probe Calibration } \\
\text { 1. Method } \\
\text { 2. Timing }\end{array}$ & $\begin{array}{l}\text { 1. Equipment Positioning } \\
\text { 2. Time Insertion } \\
\text { 3. Time Removal }\end{array}$ & $\begin{array}{l}\text { 1. Placement Check } \\
\text { 2. Timing }\end{array}$ & $\begin{array}{l}\text { Frequency of } \\
\text { Measurement }\end{array}$ & Particular Precautions \\
\hline $\begin{array}{c}{[22]} \\
\text { Viskjer and Sjostrom } \\
2017\end{array}$ & $\begin{array}{c}\text { "Any visible } \\
\text { regurgitation of gastric } \\
\text { content through the } \\
\text { mouth" } \\
\text { Direct visualisation }\end{array}$ & $\begin{array}{l}\text { "Reflux of gastric } \\
\text { content into the } \\
\text { oesophagus" } \\
\text { pH value }<4.0 \text { in the } \\
\text { distal oesophagus }\end{array}$ & Oesophageal pH meter & $\begin{array}{c}\text { 1. Two-point } \\
\text { calibration (buffer } \\
\text { solutions pH } 1.07 \text { and } \\
7.01 \text { ) } \\
\text { 2. Before probe } \\
\text { placement in each dog }\end{array}$ & $\begin{array}{l}\text { 1. } \mathrm{pH} \text { catheter introduced } \\
\text { through the oropharynx into } \\
\text { the oesophagus, advanced a } \\
\text { fixed distance into the } \\
\text { oesophagus on the basis of the } \\
\text { distance from the most rostral } \\
\text { incisor tooth on the mandible } \\
\text { to the cranial margin of the } \\
\text { head of the } 10 \text { th rib } \\
2 . \mathrm{N} / \mathrm{A} \\
\text { 3. After the surgical procedure }\end{array}$ & $\begin{array}{l}\text { 1. The position of the } \\
\text { tip of the catheter in the } \\
\text { distal portion of the } \\
\text { oesophagus was } \\
\text { confirmed } \\
\text { radiographically } \\
\text { 2. N/A }\end{array}$ & $\begin{array}{l}\text { Measurement } \\
\text { every fourth } \\
\text { second } \\
\text { (frequency } \\
0.25 \mathrm{~Hz} \text { ) }\end{array}$ & $\begin{array}{l}\text { Catheter secured to the } \\
\text { mandible with } \\
\text { adhesive tape. } \\
\text { Dogs' position and } \\
\text { duration of anaesthesia } \\
\text { recorded }\end{array}$ \\
\hline$\stackrel{[4]}{\text { Lambertini et al., } 2020}$ & N/A & $\begin{array}{l}\text { "Reflux of gastric } \\
\text { content into the } \\
\text { oesophagus" } \\
\text { Decrease in } \\
\text { oesophageal pH to a } \\
\text { value }<4.0 \text { (acidic } \\
\text { reflux) or as an increase } \\
\text { to a value }>7.5 \text { (biliary } \\
\text { reflux) for at least } 30 \mathrm{~s}\end{array}$ & Oesophageal pH meter & $\begin{array}{l}\text { 1. Two-point } \\
\text { calibration (buffer } \\
\text { solutions pH } 4.0 \text { and } \\
7.0 \text { ) } \\
2.1 \mathrm{~h} \text { prior to the } \\
\text { procedure }\end{array}$ & $\begin{array}{l}\text { 1. Probe into the oesophagus } \\
\text { for a length equal to the } \\
\text { distance between the incisor } \\
\text { tooth and the cranial border of } \\
\text { the 10th rib } \\
\text { 2. Soon after intubation } \\
\text { 3. Probe removed at the end of } \\
\text { the endoscopy of the upper } \\
\text { gastrointestinal tract in the } \\
\text { END group or immediately } \\
\text { before extubation in the ORT } \\
\text { group }\end{array}$ & $\begin{array}{l}\text { Confirmed directly } \\
\text { under endoscopic view } \\
\text { in the END group dogs, } \\
\text { or by fluorospic } \\
\text { evaluation (lateral view } \\
\text { of the thorax) in the } \\
\text { ORT group dogs. } \\
\text { Fluoroscopic } \\
\text { examination carried } \\
\text { out, passing through } \\
\text { the surgical table from } \\
\text { below, before the } \\
\text { preparation of the } \\
\text { surgical field }\end{array}$ & $\begin{array}{l}\text { Continuously } \\
\text { recorded every } 1 \\
\text { s from the probe } \\
\text { insertion up to } \\
\text { its removal }\end{array}$ & $\begin{array}{l}\text { Probe fixed to the } \\
\text { canine tooth with tape } \\
\text { in order to prevent its } \\
\text { dislodgement. } \\
\text { Dogs in END group } \\
\text { maintained in left } \\
\text { lateral recumbency. } \\
\text { Dogs in the ORT group } \\
\text { into the recumbency } \\
\text { required for the } \\
\text { surgical procedure. } \\
\text { (recorded). Surgical } \\
\text { table always parallel to } \\
\text { floor. }\end{array}$ \\
\hline $\begin{array}{l}\text { [23] } \\
\text { Benzimra et al., } 2020\end{array}$ & N/A & $\begin{array}{l}\text { Presence gas, fluid, or } \\
\text { alimentary contents in } \\
\text { the caudal oesophagus } \\
\text { on CT images }\end{array}$ & $\begin{array}{l}\text { Oesophageal content } \\
\text { retrospectively } \\
\text { assessed on plain and } \\
\text { myelo-CT scans }\end{array}$ & N/A & $\begin{array}{l}\text { CT examination of the } \\
\text { thoracolumbar spine in which } \\
\text { the field of view allowed } \\
\text { visualization of the full } \\
\text { thoracic path of the } \\
\text { oesophagus and the entire } \\
\text { stomach. } \\
\text { Caudal portion of the thoracic } \\
\text { oesophagus evaluated from } \\
\text { the base of the heart to the } \\
\text { cardia }\end{array}$ & N/A & $\begin{array}{l}\text { Retrospective } \\
\text { analysis }\end{array}$ & $\begin{array}{c}\text { All qualitative } \\
\text { assessments were } \\
\text { performed by a } \\
\text { third-year ECVDI } \\
\text { resident using a } \\
\text { dedicated DICOM } \\
\text { viewer }\end{array}$ \\
\hline
\end{tabular}




\section{References}

1. Lamata, C.; Loughton, V.; Jones, M.; Alibhai, H.; Armitage-Chan, E.; Walsh, K.; Brodbelt, D. The risk of passive regurgitation during general anaesthesia in a population of referred dogs in the UK. Vet. Anaesth. Analg. 2012, 39, 266-274. [CrossRef]

2. Wilson, D.V.; Evans, A.T.; Miller, R. Effects of preanesthetic administration of morphine on gastroesophageal reflux and regurgitation during anesthesia in dogs. Am. J. Vet. Res. 2005, 66, 386-390. [CrossRef]

3. Savvas, I.; Raptopoulos, D.; Rallis, T. A “Light Meal” Three Hours Preoperatively Decreases the Incidence of Gastro-Esophageal Reflux in Dogs. J. Am. Anim. Hosp. Assoc. 2016, 52, 357-363. [CrossRef] [PubMed]

4. Lambertini, C.; Pietra, M.; Galiazzo, G.; Torresan, F.; Pinna, S.; Pisoni, L.; Romagnoli, N. Incidence of Gastroesophageal Reflux in Dogs Undergoing Orthopaedic Surgery or Endoscopic Evaluation of the Upper Gastrointestinal Tract. Vet. Sci. 2020, 7, 144. [CrossRef] [PubMed]

5. Roush, J.K.; Keene, B.W.; Eicker, S.W.; Bjorling, D.E. Effects of atropine and glycopyrrolate on esophageal, gastric, and tracheal $\mathrm{pH}$ in anesthetized dogs. Vet. Surg. 1990, 19, 88-92. [CrossRef] [PubMed]

6. Galatos, A.D.; Raptopoulos, D. Gastro-oesophageal reflux during anaesthesia in the dog: The effect of age, positioning and type of surgical procedure. Vet. Rec. 1995, 137, 513-516. [CrossRef] [PubMed]

7. Galatos, A.D.; Raptopoulos, D. Gastro-oesophageal reflux during anaesthesia in the dog: The effect of preoperative fasting and premedication. Vet. Rec. 1995, 137, 479-483. [CrossRef]

8. Wilson, D.V.; Boruta, D.T.; Evans, A.T. Influence of halothane, isoflurane, and sevoflurane on gastroesophageal reflux during anesthesia in dogs. Am. J. Vet. Res. 2006, 67, 1821-1825. [CrossRef]

9. Wilson, D.V.; Evans, A.T.; Mauer, W.A. Influence of metoclopramide on gastroesophageal reflux in anesthetized dogs. Am. J. Vet. Res. 2006, 67, 26-31. [CrossRef]

10. Wilson, D.V.; Tom Evans, A.; Mauer, W.A. Pre-anesthetic meperidine: Associated vomiting and gastroesophageal reflux during the subsequent anesthetic in dogs. Vet. Anaesth. Analg. 2007, 34, 15-22. [CrossRef]

11. Wilson, D.V.; Evans, A.T. The effect of topical treatment on esophageal pH during acid reflux in dogs. Vet. Anaesth. Analg. 2007, 34, 339-343. [CrossRef]

12. Anagnostou, T.L.; Savvas, I.; Kazakos, G.M.; Ververidis, H.N.; Haritopoulou, M.R.; Rallis, T.S.; Raptopoulos, D. Effect of endogenous progesterone and oestradiol-17beta on the incidence of gastro-oesophageal reflux and on the barrier pressure during general anaesthesia in the female dog. Vet. Anaesth. Analg. 2009, 36, 308-318. [CrossRef] [PubMed]

13. Panti, A.; Bennett, R.C.; Corletto, F.; Brearley, J.; Jeffery, N.; Mellanby, R.J. The effect of omeprazole on oesophageal pH in dogs during anaesthesia. J. Small Anim. Pract. 2009, 50, 540-544. [CrossRef]

14. Favarato, E.S.; de Souza, M.V.; dos Santos Costa, P.R.; Pompermayer, L.G.; Campos Favarato, L.S.; Ribeiro Júnior, J.I. Ambulatory esophageal pHmetry in healthy dogs with and without the influence of general anesthesia. Vet. Res. Commun. 2011, 35, $271-282$. [CrossRef]

15. Favarato, E.S.; Souza, M.V.; Costa, P.R.; Favarato, L.S.; Nehme, R.C.; Monteiro, B.S.; Bonfa, L.P. Evaluation of metoclopramide and ranitidine on the prevention of gastroesophageal reflux episodes in anesthetized dogs. Res. Vet. Sci. 2012, 93, 466-467. [CrossRef]

16. Zacuto, A.C.; Marks, S.L.; Osborn, J.; Douthitt, K.L.; Hollingshead, K.L.; Hayashi, K.; Kapatkin, A.S.; Pypendop, B.H.; Belafsky, P.C. The influence of esomeprazole and cisapride on gastroesophageal reflux during anesthesia in dogs. J. Vet. Intern. Med. 2012, 26, 518-525. [CrossRef] [PubMed]

17. Johnson, R.A. Maropitant prevented vomiting but not gastroesophageal reflux in anesthetized dogs premedicated with acepromazine-hydromorphone. Vet. Anaesth. Analg. 2014, 41, 406-410. [CrossRef] [PubMed]

18. Anagnostou, T.L.; Savvas, I.; Kazakos, G.M.; Ververidis, H.N.; Psalla, D.; Kostakis, C.; Skepastianos, P.; Raptopoulos, D. The effect of the stage of the ovarian cycle (anoestrus or dioestrus) and of pregnancy on the incidence of gastro-oesophageal reflux in dogs undergoing ovariohysterectomy. Vet. Anaesth. Analg. 2015, 42, 502-511. [CrossRef] [PubMed]

19. Anagnostou, T.L.; Kazakos, G.M.; Savvas, I.; Kostakis, C.; Papadopoulou, P. Gastro-oesophageal reflux in large-sized, deepchested versus small-sized, barrel-chested dogs undergoing spinal surgery in sternal recumbency. Vet. Anaesth. Analg. 2017, 44, 35-41. [CrossRef]

20. Shaver, S.L.; Barbur, L.A.; Jimenez, D.A.; Brainard, B.M.; Cornell, K.K.; Radlinsky, M.G.; Schmiedt, C.W. Evaluation of Gastroesophageal Reflux in Anesthetized Dogs with Brachycephalic Syndrome. J. Am. Anim. Hosp. Assoc. 2017, 53, 24-31. [CrossRef] [PubMed]

21. Torrente, C.; Vigueras, I.; Manzanilla, E.G.; Villaverde, C.; Fresno, L.; Carvajal, B.; Finana, M.; Costa-Farre, C. Prevalence of and risk factors for intraoperative gastroesophageal reflux and postanesthetic vomiting and diarrhea in dogs undergoing general anesthesia. J. Vet. Emerg. Crit. Care (San Antonio) 2017, 27, 397-408. [CrossRef]

22. Viskjer, S.; Sjostrom, L. Effect of the duration of food withholding prior to anesthesia on gastroesophageal reflux and regurgitation in healthy dogs undergoing elective orthopedic surgery. Am. J. Vet. Res. 2017, 78, 144-150. [CrossRef] [PubMed]

23. Benzimra, C.; Cerasoli, I.; Rault, D.; Chalvet-Monfray, K.; Cauvin, E.; Couturier, L.; Gatel, L. Computed tomographic features of gastric and esophageal content in dogs undergoing CT myelography and factors influencing the presence of esophageal fluid. $J$. Vet. Sci. 2020, 21, e84. [CrossRef]

24. Cheng, K.L.; Zhu, D.-M. On Calibration of pH Meters. Sensors 2005, 5, 209-219. [CrossRef] 
25. Waterman, A.E.; Hashim, M.A. Measurement of the length and position of the lower oesophageal sphincter by correlation of external measurements and radiographic estimations in dogs. Vet. Rec. 1991, 129, 261-264. [CrossRef]

26. Pearson, H.; Darke, P.G.; Gibbs, C.; Kelly, D.F.; Orr, C.M. Reflux oesophagitis and stricture formation after anaesthesia: A review of seven cases in dogs and cats. J. Small Anim. Pract. 1978, 19, 507-519. [CrossRef]

27. Ovbey, D.H.; Wilson, D.V.; Bednarski, R.M.; Hauptman, J.G.; Stanley, B.J.; Radlinsky, M.G.; Larenza, M.P.; Pypendop, B.H.; Rezende, M.L. Prevalence and risk factors for canine post-anesthetic aspiration pneumonia (1999-2009): A multicenter study. Vet. Anaesth. Analg. 2014, 41, 127-136. [CrossRef]

28. Nehra, D.; Howell, P.; Williams, C.P.; Pye, J.K.; Beynon, J. Toxic bile acids in gastro-oesophageal reflux disease: Influence of gastric acidity. Gut 1999, 44, 598-602. [CrossRef]

29. Nehra, D.; Howell, P.; Pye, J.K.; Beynon, J. Assessment of combined bile acid and pH profiles using an automated sampling device in gastro-oesophageal reflux disease. Br. J. Surg. 1998, 85, 134-137. [CrossRef]

30. Tarvin, K.M.; Twedt, D.C.; Monnet, E. Prospective Controlled Study of Gastroesophageal Reflux in Dogs with Naturally Occurring Laryngeal Paralysis. Vet. Surg. 2016, 45, 916-921. [CrossRef] 